\title{
Effectiveness of prayer in reducing anxiety in cancer patients
}

\author{
A EFETIVIDADE DA PRECE NA REDUÇÃO DA ANSIEDADE EM PACIENTES COM CÂNCER \\ LA EFECTIVIDAD DE LA PLEGARIA EN LA REDUCCIÓN DE LAANSIEDAD EN PACIENTES \\ CON CÁNCER
}

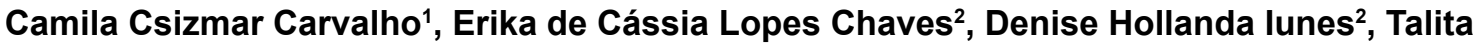 \\ Prado Simão ${ }^{3}$, Cristiane da Silva Marciano Grasselli ${ }^{2}$, Cristiane Giffoni Braga ${ }^{4}$
}

\begin{abstract}
Objective: To evaluate the effect of prayer on anxiety in cancer patients undergoing chemotherapy. Method: Quasi-experimental study, with pre and post-intervention. Twenty patients admitted to treatment of continuous intravenous chemotherapy were recruited. The volunteers were evaluated through interviews using a questionnaire of sociodemographic, clinical and spiritual characteristics, the Index of Religiosity Duke University and the State-Trait Anxiety Inventory. Vital signs were measured and collected salivary cortisol. The intervention was applied prayer and data collection occurred in three phases: first collection (baseline), pre and post-intervention. Results: The data found between the pre and post-intervention samples showed different statistically significant for state anxiety $(p=<0.00)$, blood pressure (systolic, $p=0.00$, diastolic, $p=<0.00$ ) and respiratory rate $(p=0.04)$. Conclusion: Prayer, therefore, proved to be an effective strategy in reducing the anxiety of the patient undergoing chemotherapy.
\end{abstract}

\section{DESCRIPTORS}

Neoplasms

Drug therapy

Spirituality

Religion

Anxiety

Oncology nursing

\section{RESUMO}

Objetivo: Avaliar o efeito da prece sobre a ansiedade de pacientes com câncer em tratamento quimioterápico. Método: Estudo quase experimental com pré e pós-intervenção. Foram recrutados 20 pacientes internados em tratamento de quimioterapia endovenosa contínua. Os voluntários foram avaliados por meio de entrevista, utilizando um questionário de características sociodemográficas, clínicas e espirituais, o Índice de Religiosidade da Universidade de Duke - DUREL e o Inventário de Ansiedade Traço-Estado. Foram aferidos os sinais vitais e coletado o cortisol salivar. A intervenção aplicada foi a prece e a coleta de dados ocorreu em três momentos: primeira coleta (basal), pré e pós-intervenção. Resultados: Os dados encontrados entre as coletas pré e pós-intervenção revelaram diferenças estatisticamente significativas para o estado de ansiedade $(p=<0,00)$, a pressão arterial (sistólica, $p=0,00$; diastólica, $p=<0,00)$ e a frequência respiratória $(p=0,04)$. Conclusão: A prece demonstrou ser uma estratégia eficiente na redução da ansiedade do paciente em tratamento de quimioterapia.

DESCRITORES
Neoplasias
Quimioterapia
Espiritualidade
Religião
Ansiedade
Enfermagem oncológica

\section{RESUMEN}

Objetivo: Evaluar el efecto de la plegaria sobre la ansiedad de pacientes con cáncer en tratamiento quimioterápico. Método: Estudio casi experimental con pre y post intervención. Fueron reclutados 20 pacientes hospitalizados en tratamiento de quimioterapia endovensa continua. Los voluntarios fueron evaluados por medio de encuesta, utilizándose un cuestionario de rasgos sociodemográficos, clínicos y espirituales, el Índice de Religiosidad de la Universidad de Duke - DUREL y el Inventario de Ansiedad Trazo-Estado. Fueron verificadas las señales vitales y recogido el cortisol de la saliva. La intervención aplicada fue la plegaria, y la recolección de datos sucedió en tres momentos: primera recolección (basal), pre y post intervención. Resultados: Los datos encontrados entre las recolecciones pre y post intervención revelaron diferencias estadísticamente significativas para el estado de ansiedad $(p=<0,00)$, la presión arterial (sistólica, $p=0,00$; diastólica, $p=<0,00$ ) y la frecuencia respiratoria $(p=0,04)$. Conclusión: La plegaria demostró ser una estrategia eficiente en la reducción de la ansiedad del paciente en tratamiento de quimioterapia.

\section{DESCRIPTORES}

Neoplasias

Quimioterapia

Espiritualidad

Religión

Ansiedad

Enfermería oncológica

\footnotetext{
"Extracted from the master's thesis "Efeito da prece sobre a ansiedade de pacientes submetidos ao tratamento quimioterápico," Nursing Graduate Program, Federal University of Alfenas, Minas Gerais (MG), Brazil, 2013. ${ }^{1}$ Master of Nursing, Federal University of Alfenas, Alfenas, MG, Brazil. ${ }^{2}$ Professor, Federal University of Alfenas, Alfenas, MG, Brazil. ${ }^{3}$ Nursing doctoral student, University of São Paulo at Ribeirão Preto College of Nursing, Ribeirão Preto, São Paulo, Brazil. ${ }^{4}$ Professor, Wenceslau Braz Nursing School, Itajubá, MG, Brazil.
}

$\begin{aligned} \begin{array}{r}\text { Rev Esc Enferm USP } \\ \text { 2014; 48(4):684-90 } \\ \text { www.ee.usp.br/reeusp/ }\end{array} & \begin{array}{l}\text { Received: 05/21/2014 } \\ \text { Approved: } 07 / 12 / 2014\end{array}\end{aligned}$




\section{INTRODUCTION}

Cancer is a stigmatized illness, for it brings suffering and changes to a person's life ${ }^{(1)}$, as well as possibly causing depression and anxiety ${ }^{(2)}$. People affected by cancer experience hospitalization, which includes hospital routine, waiting for information, and a restricted number of visitors, all of which can cause various reactions to the situation ${ }^{(3)}$.

In light of the above and the stigma surrounding the illness, feelings of fear and insecurity can arise, potentially influencing cancer treatment. Thus, reducing patients' anxiety is necessary ${ }^{(3)}$. The term anxiety comes from the Greek word anshein, which means to oppress, to suffocate, and it can cause changes in the body, such as increased heart and respiratory rate ${ }^{(4)}$. In addition to physical alterations, social, psychological and spiritual aspects are also affected.

Nurses are the professionals who accompany patients and their families during the illness process, from diagnosis to rehabilitation. Comprehensive care must include physical, social, psychological and spiritual aspects. Nurses can treat anxiety using activities proposed by the Nursing Interventions Classification (NIC) ${ }^{(5)}$, which provides suggestions such as trying to understand the patient's point of view regarding the feared situation, listening closely, administering anxiety medication, and encouraging the family to stay with the patient, as well as others. Such interventions also include taking a calm, reassuring approach and providing patients with orientation on relaxation techniques.

In this sense, it is important for nurses to develop strategies for reducing or eliminating anxiety and calming patients. Studies have observed that spiritual experiences can reduce anxiety levels ${ }^{(6-7)}$.

Spirituality can be practiced through prayer, classified into two types: Petitions, when those who pray ask God for something for themselves; or intercession, when those who pray ask God for something on someone else's behalf $f^{(8)}$. The act of prayer is a frequent spiritual activity that promotes well-being, facilitates the health-illness process and offers health benefits ${ }^{(9)}$.

Prayer is one of the activities proposed for nursing interventions that provide spiritual support and facilitate spiritual growth ${ }^{(5)}$. It is a strategy used to meet the spiritual needs of patients and a calming technique. So why not use it for reducing anxiety?

An investigation of studies aimed at understanding prayer in a clinical context favors its use in nursing care, in order to provide patients with well-being. Furthermore, such investigations contribute to nursing knowledge and strengthen care strategies involving non-conventional therapies. It is important to conduct studies on this topic in order to evaluate the scientific effect of prayer and thus validate its use by health professionals when caring for patients ${ }^{(10)}$.
The objective of this study was to evaluate the effect of prayer on the anxiety of cancer patients submitted to chemotherapy.

\section{METHOD}

This was a quasi-experimental pre-post intervention study, conducted in the inpatient sector of a philanthropic hospital in the South of the state of Minas Gerais, Brazil. It took place between February and December 2012 with patients submitted to continuous intravenous antineoplastic chemotherapy.

We chose a convenience sample consisting of 45 patients receiving treatment in the oncology sector. Inclusion criteria were having a cancer diagnosis, being over 18 years of age, receiving chemotherapy, being willing to receive prayer and being clinically stable. Criteria for exclusion were presenting hearing or speech impairments, not being available for collection of baseline cortisol data at eight in the morning and having received fewer than three applications of chemotherapy during the data collection period.

Twenty-four patients were selected according to the inclusion criteria and four individuals left the study because their chemotherapy treatment was interrupted and/or they began to present hearing impairments. Therefore, the final sample comprised 20 patients.

Data collection consisted of evaluating signs of anxiety with the State-Trait Anxiety Inventory, measuring blood pressure, respiratory rate and heart rate and applying the prayer intervention. First, we interviewed participants using a questionnaire about sociodemographic and clinical characteristics created by the researcher based on the objectives and theme of the study, which was submitted to a pre-test refinement process.

Participants were given the Duke University Religion Index (DUREL) ${ }^{(11)}$, an instrument whose Brazilian Portuguese version has been properly validated ${ }^{(12)}$. It consists of a five-item scale measuring three dimensions of religiosity: organizational religious activity (ORA); non-organizational religious activity (NORA) and intrinsic religiosity (IR). The scores for each of the three dimensions must be considered separately and there is no need to calculate a total score ${ }^{(11)}$. For ORA and NORA, a score lower than three characterizes high levels of religious activity; greater than three, low levels of religious activity. For the RI item, a score below 7.5 characterizes high religiosity, and higher than 7.5 , low religiosity.

Subsequently, we applied the State-Trait Anxiety Inventory (STAI) ${ }^{(13)}$, validated in Brazil by Biaggio et al. ${ }^{(14)}$ It is an instrument containing 40 statements describing a person's feelings, distributed in two parts, trait (STAI-T) and state (STAI-S), each part consisting of 20 statements. Answers are given on a four-point Likert scale $(1-$ absolutely not to 
4 - very much). Scores for each subscale range from 20 to 80 points and indicate mild (0-30), moderate (31-49) and severe levels of anxiety (greater than or equal to 50$)^{(13)}$

The first sample of $1.0 \mathrm{ml}$ of saliva for salivary cortisol analysis, called basal cortisol, was gathered at 8 am with Salivette ${ }^{\circledR}$ tubes $^{(15)}$. These were stored in a thermal bag with ice and immediately sent to the laboratory for analysis, conducted with the electrochemiluminescence method. It is worth noting that whenever samples were not immediately taken to the laboratory, they were maintained at a temperature between $2^{\circ} \mathrm{C}$ and $8^{\circ} \mathrm{C}$ for a maximum of 48 hours.

Heart rate, respiratory rate and blood pressure were always measured in this sequence, $\mathbf{3 0}$ minutes after rest and with the patient sitting up against the head of the bed $^{(16)}$. Furthermore, as recommended by the adopted literature, heart and respiratory rates were measured through palpation, using a chronometer for a one-minute period. We used indirect measurement of blood pressure, through the auscultatory method, using a stethoscope and an aneroid sphygmomanometer in accordance with Brazilian Society of Cardiology guidelines ${ }^{(17)}$.

For pre-intervention data collection, participants were given the STAI-S once more, but not the STAI-T, which was applied only once in the beginning. Saliva samples and vital sign measurements were also gathered by the same examiner and with the same procedures as those adopted for basal data collection.

Soon after, the prayer intervention was carried out, created and conducted by the researcher. It was a Christian prayer, with no invocation of saints, citing Psalm 138 of the Bible, which speaks of divine omniscience: God knows all and sees all. The prayer was in the form of an audio recording 11 minutes long of a musician's voice with good diction. Participants listened to the recording using earphones with a protective plastic covering and were instructed to sit or lie comfortably with their eyes closed to promote concentration. Furthermore, they held hands with the researcher, who conducted a silent intercession prayer.

There is no gold standard available in the literature for prayer application determining its format, beginning, duration or the person who will apply the technique ${ }^{(18)}$. To guarantee the rigorousness and repeatability of the investigation, we sought to standardize the time and location of the prayer, as well as always using the same type of prayer and the same intercessor.

Thirty minutes after prayer, patients were given the STAI-S once more. Subsequently, saliva samples were gathered and vital signs measured in the standardized sequence and by the same trained examiner (post-intervention data collection).

For each of the pre-and post-intervention observations on the STAI-S, saliva samples, and vital signs, three repetitions of data collection were done in order to measure the repeatability of the observations. This was needed in order to increase the credibility of the data obtained ${ }^{(19)}$.

The control group received the same protocol, with no prayer intervention. The examiner remained beside them during the same length of time as the prayer, conducting a moment of personal interaction, which consisted of observing, listening to and giving attention to the patient. Results were charted and analyzed with the BioEstat 5.0 program. We used the two-sample t-test or the Wilcoxon signed-rank test to compare state anxiety levels, salivary cortisol, blood pressure, and heart and respiratory rates pre- and post-intervention. For comparison between control and intervention groups, we used the Mann-Whitney $\mathrm{U}$ test or t-test specific for two independent samples. A $5 \%$ significance level was adopted.

The study was approved by the research ethics committee of the Federal University of Alfenas (Protocol no. 063/2011) and data were gathered only after a Free and Informed Consent form was signed.

\section{RESULTS}

Of the 20 subjects who participated in the study, 15 (75\%) were male and five (25\%), female. Table 1 displays other investigated sociodemographic characteristics.

Table 1 - Sample sociodemographic characteristics - Alfenas, Minas Gerais, Brazil, 2012

\begin{tabular}{|c|c|c|}
\hline Sociodemographic characteristics & $f^{*}$ & $\%$ \\
\hline \multicolumn{3}{|l|}{ Age } \\
\hline$<40$ years & 2 & 10 \\
\hline 40 to 50 years & 4 & 20 \\
\hline 51 to 60 years & 11 & 55 \\
\hline 61 to 70 years & 3 & 15 \\
\hline \multicolumn{3}{|l|}{ Education Level } \\
\hline No formal schooling & 1 & 5 \\
\hline Completed Elementary School & 15 & 75 \\
\hline Completed High School & 2 & 10 \\
\hline Completed Higher Education & 2 & 10 \\
\hline \multicolumn{3}{|l|}{ Marital Status } \\
\hline Single & 2 & 10 \\
\hline Married/Cohabitation & 15 & 75 \\
\hline Divorced & 3 & 15 \\
\hline \multicolumn{3}{|l|}{ Family income } \\
\hline $\begin{array}{l}\text { Less than a monthly minimum wage } \\
\text { (MMW) }\end{array}$ & 1 & 5 \\
\hline One to three MMW & 16 & 80 \\
\hline Four to six MMW & 2 & 10 \\
\hline Does not know & 1 & 05 \\
\hline \multicolumn{3}{|l|}{ Religion } \\
\hline Catholic & 13 & 65 \\
\hline Evangelical & 6 & 30 \\
\hline No religion, but spiritualized & 1 & 5 \\
\hline Jehovah's witness & 0 & 0 \\
\hline
\end{tabular}

*frequency

\section{Rev Esc Enferm USP \\ 2014; 48(4):684-90 \\ www.ee.usp.br/reeusp/}

Effectiveness of prayer in reducing anxiety in cancer patients Carvalho CC, Chaves ECL, lunes DH, Simão $T P$, Grasselli CSM, Braga CG 
With respect to religious characteristics (Table 2), the sample revealed a high level of religiosity for the three DUREL dimensions: organizational, non-organizational and intrinsic religiosity. All patients reported prayer practice, as well as belief in its power. High religiosity was especially related to intrinsic religiosity and experiencing religiosity fully: Feeling God's presence and striving to live in accordance with one's religious belief.

Table 2 - Description of subject's religiosity according to the Duke University Religion Index (DUREL) - Alfenas, Minas Gerais, Brazil, 2012

\begin{tabular}{lcc}
\hline ORGANIZATIONAL RELIGIOUS ACTIVITY & & \\
A) How often do you attend church or other religious meetings? & $\mathrm{n}=20$ & $\%$ \\
\hline 1. More than once a week & 4 & 20 \\
2. Once a week & 5 & 25 \\
3. Two or three times a month & 2 & 10 \\
4. A few times a year & 7 & 35 \\
5. Once a year or less & 1 & 5 \\
6. Never & 1 & 5 \\
\hline
\end{tabular}

NON-ORGANIZATIONAL RELIGIOUS ACTIVITY

B) How often do you spend time in private religious activities, such as prayer, meditation or studying the Bible or other religious texts?

\begin{tabular}{lcc}
\hline 1. More than once a day & 4 & 20 \\
2. Once a week & 13 & 65 \\
3. Two or three times a month & 0 & 0 \\
4. A few times a year & 0 & 0 \\
5. Once a year or less & 02 & 10 \\
6. Never & 01 & 05 \\
\hline
\end{tabular}

INTRINSIC RELIGIOSITY

C) In my life, I experience the presence of the Divine (i.e., God).

\begin{tabular}{lcc}
\hline 1. Definitely true of me & 19 & 95 \\
2. Tends to be true & 1 & 5 \\
3. Unsure & 0 & 0 \\
4. Tends $n o t$ to be true & 0 & 0 \\
5. Definitely not true & 0 & 0 \\
\hline
\end{tabular}

D) My religious beliefs are what really lie behind my whole approach to life.

\begin{tabular}{lcc}
\hline 1. Definitely true of me & 18 & 90 \\
2. Tends to be true & 0 & 0 \\
3. Unsure & 1 & 5 \\
4. Tends $n o t$ to be true & 1 & 5 \\
5. Definitely $n o t$ true & 0 & 0 \\
\hline
\end{tabular}

E) I try hard to carry my religion over into all other dealings in life.

\begin{tabular}{lcc} 
1. Definitely true of me & 16 & 80 \\
2. Tends to be true & 1 & 5 \\
3. Unsure & 2 & 10 \\
4. Tends $n$ ot to be true & 1 & 5 \\
5. Definitely not true & 0 & 0 \\
\hline
\end{tabular}

Regarding clinical characteristics, only two individuals presented comorbidities such as diabetes and hypertension. With respect to the cancer's location, 10 (50\%) presented head and neck cancer; four (20\%), intestinal; two (10\%), stomach; two (10\%), bone marrow; one (5\%), liver; and one $(5 \%)$, prostate. Considering time of illness discovery, 12 (60\%) reported having discovered the disease one to six months before beginning treatment; four (20\%), six to 10 months; and the others (20\%), more than 10 months before.

The anxiety profile of the sample, as measured by the complete STAI the first time, before conducting the intervention, displayed moderate levels of anxiety (Table 3 ).

Table 3 - Baseline anxiety profile - Alfenas, Minas Gerais, Brazil, 2012

\begin{tabular}{lc}
\hline \multicolumn{1}{c}{ Variables } & $\begin{array}{c}\text { Group } \\
(\overline{\mathbf{x}} \pm \boldsymbol{s})\end{array}$ \\
\hline Trait anxiety & $36.2 \pm 9.9$ \\
State anxiety & $35.2 \pm 7.1$ \\
Salivary cortisol (nmol/L) & $9.7 \pm 6.5$ \\
Systolic BP $(\mathrm{mmHg})$ & $118.5 \pm 16.9$ \\
Diastolic BP (mmHg) & $78.2 \pm 14.1$ \\
Respiration (breaths per minute) & $18.7 \pm 3.1$ \\
Heart rate (bpm) & $71.1 \pm 9.4$ \\
\hline
\end{tabular}

Anxiety state was influenced by non-organizational religious activity, according to Spearman's coefficient $(p=0.01)$, and displayed a correlation with age group $(p=0.01)$. No other sociodemographic characteristic influenced anxiety in this study.

When comparing all pre- and post-intervention means, we identified modified values for state anxiety, blood pressure and respiration rate, confirming the effectiveness of prayer on these variables (Table 4).

Table 4 - Comparison between pre-and post-intervention means - Alfenas, Minas Gerais, Brazil, 2012

\begin{tabular}{|c|c|c|c|c|c|}
\hline \multirow[t]{2}{*}{ Variables } & \multicolumn{2}{|c|}{$\begin{array}{c}\text { Pre- } \\
\text { intervention }\end{array}$} & \multicolumn{2}{|c|}{$\begin{array}{l}\text { Post- } \\
\text { intervention }\end{array}$} & \multirow{2}{*}{ p-value* } \\
\hline & $\overline{\mathbf{x}}$ & $s$ & $\overline{\mathbf{x}}$ & $s$ & \\
\hline State anxiety & 33.52 & 4.92 & 28.42 & 5.57 & $<0$ \\
\hline $\begin{array}{l}\text { Salivary cortisol } \\
(\mathrm{nmol} / \mathrm{L})\end{array}$ & 10.31 & 6.66 & 10.61 & 6.61 & 0.57 \\
\hline Systolic BP (mmHg) & 122.08 & 12.98 & 115.33 & 11.58 & 0 \\
\hline Diastolic BP (mmHg) & 80.83 & 10.37 & 76.5 & 9.6 & $<0$ \\
\hline $\begin{array}{l}\text { Respiration (breaths per } \\
\text { minute) }\end{array}$ & 20.43 & 4.58 & 18.2 & 3.33 & 0.04 \\
\hline Heart rate (bpm) & 70.58 & 10.24 & 68.8 & 6.31 & 0.07 \\
\hline
\end{tabular}

According to the STAI-S, anxiety levels were reduced after prayer at each moment. Blood pressure was reduced in the three measurements after prayer, with values below $120 / 80 \mathrm{mmHg}$, which is considered an adequate value according to the Brazilian Society of Cardiology ${ }^{(17)}$. Respiratory rate was also reduced significantly, all values registering above normal levels before intervention but showing a mean level of $18 \mathrm{rpm}$ after prayer, which is within the standard range of 12 to $20 \mathrm{rpm}^{(16)}$. Values related to anxiety levels and vital signs were reduced after each intervention and for all three repetitions of pre- and post-intervention observation (Table 5). 
Table 5 - Mean $(\overline{\mathbf{x}})$ and sample standard deviation $(s)$ of data collected at three repetitions of pre- and post-intervention observation - Alfenas, Minas Gerais, Brazil, 2012

\begin{tabular}{|c|c|c|c|c|}
\hline & Variables & $\begin{array}{c}1^{\text {st }} \text { repetition } \\
(\overline{\mathrm{x}} \pm s)\end{array}$ & $\begin{array}{c}2^{\text {nd }} \text { repetition } \\
(\bar{x} \pm s)\end{array}$ & $\begin{array}{c}3^{\text {rd }} \text { repetition } \\
(\bar{x} \pm s)\end{array}$ \\
\hline \multirow{6}{*}{ 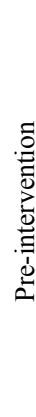 } & State anxiety & $34.20 \pm 5.99$ & $33.35 \pm 5.30$ & $33.00 \pm 6.29$ \\
\hline & $\begin{array}{l}\text { Salivary cortisol } \\
(\mathrm{nmol} / \mathrm{L})\end{array}$ & $9.65 \pm 7.71$ & $10.55 \pm 8.09$ & $9.40 \pm 6.75$ \\
\hline & $\begin{array}{l}\text { Systolic BP } \\
(\mathrm{mmHg})\end{array}$ & $119.75 \pm 14.64$ & $121.25 \pm 18.05$ & $125.25 \pm 18.46$ \\
\hline & $\begin{array}{l}\text { Diastolic BP } \\
(\mathrm{mmHg})\end{array}$ & $79.00 \pm 12.52$ & $80.50 \pm 17.31$ & $83.00 \pm 13.42$ \\
\hline & $\begin{array}{l}\text { Respiration } \\
\text { (breaths per } \\
\text { minute) }\end{array}$ & $27.14 \pm 23.55$ & $23.00 \pm 20.25$ & $23.95 \pm 20.06$ \\
\hline & $\begin{array}{l}\text { Heart rate } \\
\text { (bpm) }\end{array}$ & $68.28 \pm 21.27$ & $74.43 \pm 14.19$ & $74.67 \pm 12.39$ \\
\hline \multirow{6}{*}{ 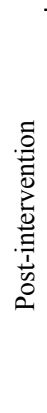 } & State anxiety & $31.48 \pm 18.98$ & $32.43 \pm 18.72$ & $33.00 \pm 18.67$ \\
\hline & $\begin{array}{l}\text { Salivary cortisol } \\
(\mathrm{nmol} / \mathrm{L})\end{array}$ & $9.75 \pm 7.68$ & $11.00 \pm 7.67$ & $9.70 \pm 7.02$ \\
\hline & $\begin{array}{l}\text { Systolic BP } \\
\text { (mmHg) }\end{array}$ & $115.25 \pm 13.32$ & $115.25 \pm 16.18$ & $115.50 \pm 15.38$ \\
\hline & $\begin{array}{l}\text { Diastolic BP } \\
(\mathrm{mmHg})\end{array}$ & $77.00 \pm 8.64$ & $76.00 \pm 14.20$ & $76.50 \pm 14.24$ \\
\hline & $\begin{array}{l}\text { Respiration } \\
\text { (breaths per } \\
\text { minute) }\end{array}$ & $18.05 \pm 3.84$ & $18.50 \pm 3.91$ & $18.05 \pm 3.47$ \\
\hline & $\begin{array}{l}\text { Heart rate } \\
(\mathrm{bpm})\end{array}$ & $68.80 \pm 9.52$ & $68.95 \pm 8.96$ & $68.65 \pm 7.06$ \\
\hline
\end{tabular}

\section{DISCUSSION}

In oncology, patients' lives are changed after diagnosis and treatment; moreover, each patient responds differently to situations experienced during hospitalization, which can generate anxiety ${ }^{(2-3)}$. This was the case for the subjects of this study, who required hospitalization in order to receive continuous intravenous chemotherapy.

Among these patients, we observed a moderate level of both trait (mean value 36.2) and state (mean value 35.2) anxiety, in response to the illness, treatment and hospitalization process. Trait anxiety presented a correlation with age group $(p=0.01 ; r=0.52)$, for the older the interviewee, the higher the anxiety level. Participants' state anxiety presented a significant relation $(p=0.01$; $r=0.54$ ) with non-organizational religious activity, which is related to individual religious activity. Therefore, the stronger the patients' personal relationship with God, the less anxious they were.

Findings of a previous study ${ }^{(20)}$ demonstrated that cancer patients submitted to chemotherapy used religious/ spiritual coping methods for dealing with the disease and would have liked to receive spiritual care from health professionals. In this sense, the use of comprehensive practices or even practices directed toward patients' spiritual dimension can be an important strategy to help cope with cancer, its treatment and any consequent anxiety.

Furthermore, spirituality by means of prayer is beneficial, for it leads to tension relief, increased hope and reduced anxiety ${ }^{(21)}$. Carrying out spiritual care is a challenge and requires that spirituality be included in professional training and that investments be made in research in order to solidify knowledge of the phenomenon. Religiosity/spirituality can be considered a coping strategy for patients diagnosed with cancer, whose treatment is permeated by stressful events, given the impact that the illness has on the person's life ${ }^{(7)}$.

In the present study we used the spiritual practice of prayer. Its use as a supporting therapy for cancer treatment must be strengthened, for we found that it caused a positive effect on people's lives ${ }^{(22)}$. The intensity of participants' anxiety was reduced, going from moderate to mild $(p<0.00)$ after prayer was applied.

When comparing the results of pre- and post-intervention data collection, we observed significant alterations in anxiety levels $(p<0.00)$, respiratory rate $(p=0.04)$ and blood pressure $(p=0.00)$ of patients who received prayer. Among other alterations, anxiety causes increased blood pressure, heart rate and respiratory rate ${ }^{(4)}$. Thus, we can infer that prayers can reduce the intensity of anxiety, blood pressure and respiratory rate levels of patients.

Prayer can be a significant practice for stabilizing vital signs, not only for people receiving chemotherapy, but also for other patients or even people in good health. This was the case in a study that used the Hail Mary prayer in a sample of 23 healthy adults. The results displayed reduced respiratory rate and improved cardiac function parameters ${ }^{(23)}$. Praying the rosary, in addition to being a religious practice, was found to be a health practice; a result that also occurred in the present study with patients receiving chemotherapy, but with a Christian prayer that did not invoke saints and was conducted in an ecumenical manner.

Prayer did not present a significant correlation $(p=0.57)$ with participants' salivary cortisol levels. In this sense, the literature has demonstrated that the response of salivary cortisol to conditions of stress and anxiety can vary, for cortisol can present elevated levels in response to acute stress or be reduced with chronic stress ${ }^{(15)}$.

Prayer can be a care option that contributes beneficially to conventional treatment. It also attends to the spiritual dimension of patients hospitalized for chemotherapy. The application of prayer provides a new perspective for nursing care of these patients.

\section{CONCLUSION}

Prayer was effective in reducing the anxiety of patients receiving chemotherapy. It is important to assess the anxiety of these patients, especially those submitted to continuous intravenous treatment. Interventions directed at reducing anxiety can help patients with treatment adhesion and provide them with a greater sense of well-being. 
The use of various means of investigating anxiety facilitates and reinforces its identification. Among those used in this study, measuring vital signs is effective because they are considered to be indicators of bodily vital functions and are a routine part of nursing clinical practice. It is a simple technique that is cost-free and requires little time. The application of a psychometric instrument is also a simple, quick method of self-evaluation; however, a trained person is required to calculate the score. On the other hand, salivary cortisol analysis is more costly; even though it is not an invasive procedure, it requires laboratory analysis and also requires a trained professional for sample gathering and pertinent recommendations.

We concluded that nursing clinical practice places professionals in a position to investigate patient's anxiety and treat it through alternative therapies such as prayer. This method attends to patients' spiritual dimension and was found to be effective in reducing anxiety. Furthermore, its use is simple and can be continuous, resulting in no finan-

\section{REFERENCES}

1. Souza BF, Pires FH, Dewulf NLS, Inocenti A, Silva AE, Miasso Al. Patients on chemotherapy: depression and adherence to treatment. Rev Esc Enferm USP. 2013; 47(1):61-8.

2. Jadoon NA, Munir W, Shahzad MA, Choudhry ZS. Assessment of depression and anxiety in adult câncer outpatients: a crosssectional study. BMC Cancer. 2010;10:594.

3. Silva MEDC, Silva LDC, Dantas Araújo DOR, Duarte IS, Sousa JFM. Assistência de enfermagem ao paciente oncológico no hospital. Rev Enferm UFPI. 2013;2(n.esp):69-75.

4. Lin MF, Hsieh YJ, Hsu YY, Fetzer S, Hsu MC. A randomized controlled trial of the effect of music therapy and verbal relaxation on chemotherapy-induced anxiety. J Clin Nurs. 2011;20(7-8):988-99.

5. McCloskey JC, Bulechek GM. Classificação das intervenções de enfermagem. Porto Alegre: Artmed; 2010.

6. Barrera TL, Zeno D, Buch AL, Barber CR, Stanley MA. Integrating religion and spirituality into treatment for late-life anxiety: three case studies. Cogn Behav Pract. 2012;19(2):346-58.

7. Fornazari SA, Ferreira RER. Religiosidade/espiritualidade em pacientes oncológicos: qualidade de vida e saúde. Psicol Teor Pesq. 2010;26(2):265-72.

8. Tosta CE. A prece cura? Brasília Med. 2004;41(1-4):38-45.

9. Caldeira S. Cuidado espiritual: rezar como intervenção de enfermagem. CuidArte Enferm. 2009;3(2):157-64. cial costs and no change to the hospital service routine. However, its use as a technique must still be tested.

One of the limitations of this study relates to the sample size, which prevents the generalization of the results. This calls for replication of the investigation with a larger sample size; especially with a clinical trial model so that control and treatment group results can be compared. Nonetheless, the results of the study have implications for nursing clinical practice, for it offers a standardized prayer protocol that lasts a maximum of 10 minutes. The prayer can be recorded and offered to patients to listen through headphones during a chemotherapy session; it can also be conducted by nurses themselves, in the form of intercession, should the patient so desire.

Nursing staff can use prayer as a strategy for providing patients with spiritual support, in order to attend to the needs related to their spirituality or even to help the patient cope with the illness, its treatment and consequent anxiety.

10. Tosta CE. Prece e cura. In: Teixeira EFB, Müller MC, Silva JDT. Espiritualidade e qualidade de vida. Porto Alegre: Ed.PUCRS; 2004. p.105-24.

11. Koenig H, Parkerson GR Jr, Meador KG. Religion Index for psychiatric research: a 5-item measure for use in health outcomes studies. Am J Psychiatry. 1997;154(6):885-6.

12. Taunay TCDE, Gondim FAA, Macêdo DS, Moreira-Almeida A, Gurgel LA, Andrade LMS, et al. Validação da versão brasileira da escala de religiosidade de Duke (DUREL). Rev Psiq Clín. 2012;39(4):130-5.

13. Andreatini R, Seabra ML. A estabilidade do IDATE-traço: avaliação após cinco anos. Rev ABP-APAL. 1993;15(1):21-5.

14. Biaggio AMB, Natalício L, Spielberger CD. Desenvolvimento da forma experimental em português do Inventário de Ansiedade Traço-Estado (IDATE) de Spielberger. Arq Bras Psicol. 1977;19(3):31-44.

15. Soo-Quee DK, Choon-Huat GK. The use of salivary biomarkers in occupational and environmental medicine. Occup Environ Med. 2007;64(3):202-10.

16. Potter PA, Perry AG. Fundamentos de enfermagem. Rio de Janeiro: Elsevier; 2009.

17. Sociedade Brasileira de Hipertensão; Sociedade Brasileira de Nefrologia. VI Diretrizes Brasileiras de Hipertensão. Arq Bras Cardiol. 2010;95(1 Supl.1):1-51.

18. Guimarães HP, Avezum A. O impacto da espiritualidade na saúde física. Rev Psiq Clín. 2007;34(1):88-94. 
19. Polit DF, Beck CT, Hungler BP. Fundamentos de pesquisa em enfermagem: métodos, avaliação e utilização. Porto Alegre: Artmed; 2004.

20. Mesquita AC, Chaves ECL, Avelino CCV, Nogueira DA, Panzini RG, Carvalho EC. The use of religious/spiritual coping among patients with cancer undergoing chemotherapy treatment. Rev Latino Am Enfermagem. 2013;21(2):539-45.

21. Zenevicz L, Moriguchi $\mathrm{Y}$, Madureira VSF. The religiosity in the process of living getting old. Rev Esc Enferm USP. 2013;47(2):433-9.
22. Astin JA, Stone J, Abrams DI, Moore DH, Couey P, Buscemi $\mathrm{R}$, et al. The efficacy of distant healing for human immunodeficiency virus-results of a randomized trial. Altern Ther Health Med. 2006;12(6):36-41.

23. Bernardi L, Sleight P, Bandinelli G, Cencetti S, Fattorini L, Wdowczyc-Szulc J, et al. Effect of rosary prayer and yoga mantras on autonomic cardiovascular rhythms: comparative study. BMJ. 2001;323(7327):1446-49.

\section{Financing}

Coordination for the Improvement of Higher Education Personnel (CAPES) 